\title{
Different Methods for Detecting Heterotic Groups in Maize
}

\author{
Mohammed M. El-Rouby, Mohammed H. El-Sheikh, Ahmed A. Habliza*, \\ and Emad I. Mahmoud** \\ Department of Crop science, Faulty of Agriculture (El-Shatby), Alexandria \\ University, * Program of Maize Research, Field Crop Research Institute, \\ Agriculture Research Center,
}

\begin{abstract}
Comparing between different methods for classifying 12 maize inbred lines to heterotic groups was achieved using general and specific combining ability effects; agronomic traits to the maize inbreds per se; and ISSR-markers. The results of line-tester design showed that Giza656 lines had the highest yield for the cross with Gemmiza 1021 tester (7.20 ton per hectare) at Nubaria, while Giza655 lines had the highest yield for the cross with Gemmiza 1021 tester (8.24 ton per hectare) at Gemmiza. Regarding Heterotic specific and General Combining Abilities, the inbred lines were grouped into three groups as their testers were, but groups differed from Nubaria to Gemmiza locations.

The classification due to Inter Simple Sequence Repeats markers have agreement with pedigree data more than the HSGCA and agronomic characters, because the HSGCA method affected by testers, lines, environments, and the interactions between all of them, also, agronomic character method need to plant the inbreds and evaluate them at more locations and more seasons .Furthermore, all these cautions will not discard the environmental effects but they will reduce it to the minimum values. On the other hand, molecular marker will keep time and efforts needed to evaluate the inbred lines.
\end{abstract}

Keywords: heterotic groups, molecular markers, maize breeding.

\section{Introduction}

Heterosis is a major yield factor in all breeding categories except line breeding (Schnell, 1982). To exploit heterosis in hybrid breeding, the concept of heterotic groups and patterns was suggested, (Reif, et al, 2005).

The manifestation of heterosis usually depends on genetic divergence of the two parental varieties. Genetic divergence among varieties usually is unknown, and the only recourse is to determine level of genetic divergence empirically by means of variety crosses. Genetic divergence of the parental varieties is inferred from the heterotic patterns manifested in the series of variety crosses. If heterosis manifested from the cross of two parental varieties is relatively large, it is concluded that the two parental varieties are more genetically diverse than two varieties that manifest little or no heterosis in their variety crosses. Establishment of heterotic patterns among varieties has important implications for selecting inbred lines as potential seed stocks in hybrids (Hallauer, et al., 1988)

A heterotic group is a collection of closely related inbred lines which tend to result in vigorous hybrids when crossed with lines from a different heterotic group, but not when crossed to other lines of the same heterotic group (Lee,2007). Depending on the objectives of the breeding program, breeders use different methods in selecting the best 
parents for making crosses, and for assigning lines to a particular heterotic group, including (a) pedigree relations (b) phenotypic performance for specific traits, (c) adaptability and yield stability, (d) top crosses, (e) diallel crosses, and (f) genetic distances estimated from morphological and molecular markers, (Bertan et al, 2003).

The need of genetic diversity between inbred lines used in crosses is generally accepted. In the past, general experience usually but not always showed that crosses of unrelated genotypes contributed to greater yields. It usually required extensive evaluation trials to determine the unique combination of two parental inbred lines. Although the genetic basis of the importance of genetic diversity was not clear, general experience showed that the better hybrids involved inbred lines derived from two or more genetic backgrounds (Hayes, 1956).

Melchinger and Gumber, (1998) listed the following criteria wich are useful for identifying heterotic groups and patterns 1.High mean performance and large genetic variance in the cross between heterotic groups. In other words the usefulness criterion in the population cross should be high. High per se performance and good adaptation of heterotic groups. Ideally inbred from both heterotic groups should be sufficient pollen and have high seed yields to provide adequate hybrid seeds. 2. Ability to maintain and propagate inbreds. Developing inbreds is difficult if inbreeding depression is too severe. 3. A stable cytoplasmic male sterility system, if needed.

The objectives of the present work were to: 1. Classifying 12 maize inbred lines into heterotic groups using: a. General and specific combining abilities derived from line-tester mating design (Heterotic General and Specific Combining Ability, (HSGCA method)), b. Cluster analysis for the 12 inbred lines agronomic characters.,c. Cluster analysis for its DNA amplification with Inter Simple
Sequence Repeats (ISSR) markers. 2. Comparison between previous grouping methods with pedigree information, and determining breeding value for each method.

\section{Materials and Methods}

The present work was carried out at Maize research department, Field Crop Research Institute (FCRI), Agriculture Research Center (ARC), Egypt, during the period from 2010 to 2012. The present investigation consisted of three experiments; the first one was conducted to determine general and specific combining ability effects through Line $\mathrm{x}$ Tester mating design. The second experiment was conducted to determine some agronomic traits to these inbred lines under investigation. The third experiment was conducted to apply ISSRanalysis for detection of genetic polymorphism among 15 Maize inbred lines. These experiments were performed as follows:

\section{A. Line $x$ Tester experiment}

Selected inbred lines for study:15 Maize inbred lines and its genetic background presented in Table (1) were obtained from Maize research department. Three inbred lines Giza 639, Gemmiza 1021 and, Nubaria 552 were used as a tester for the other 12 inbred lines.

\section{Experimental procedures:}

In 2010 and 2011 seasons, at Nubaria griculture Research Station farm, 12 Maize inbred lines were used as female parents and crossed with three testers in a Line $\mathrm{x}$ Tester mating design yielded 36 yellow single crosses.

In 2012, 36 single crosses and check hybrid SC- 173 were evaluated at two locations which were Nubaria and Gemmiza. A randomized complete block design with three replications was used for each location. Each experimental unit was a single-row plot with a row spacing of $0.75 \mathrm{~m}$ and length of $6 \mathrm{~m}$. Distance between two adjacent plants was $0.25 \mathrm{~m}$ and the population density was approximately 57000 
plants $\mathrm{ha}^{-1}$. Standard agronomic farming practices were followed at each experimental site. Grain yield (ton $\mathrm{ha}^{-1}$ ): weight of grain yield detected in ton per hectare estimating by adjusting the ear weight according to its shelling percent and $15.5 \%$ moisture content.

\section{Statistical analysis:}

Analysis of variance was done for each location alone, due to heterogeneity of error mean squares., 2.The procedure line $\mathrm{x}$ tester analysis according to Kempthrone (1957) was used for estimating general and specific combining ability effects were:

Lines: gi $=(\mathrm{Xi} . . / \mathrm{tr})-(\mathrm{X} . . / \mathrm{ltr})$,Testers: $\mathrm{gi}=$ $(\mathrm{X} . \mathrm{j} . / \mathrm{lr})-(\mathrm{X} . . / \mathrm{ltr}), \mathrm{Sij}=(\mathrm{Xij} / \mathrm{r})-(\mathrm{Xi} . / \mathrm{tr})-$ $(\mathrm{X} . \mathrm{j} . / \mathrm{lr})+(\mathrm{X} . . / \mathrm{ltr})$.

Where: gi $=$ general combining ability for ith inbred line, $\mathrm{Xi}$. . = total grain yield of testcrosses for ith inbred line, X... = overall total of grain yield for all crosses

$1=$ number of inbred lines, $\mathrm{t}=$ number of testers, $r=$ number of replications

$\mathrm{Sij}=$ specific combining ability for ith inbred line and jth tester, X.j. = total grain yield of testcrosses for $\mathrm{jth}$ tester.

HSGCA-method (Heterotic group's specific and general combining ability)

Heterotic group's specific and general combining ability (HSGCA) were made according to Fan et al (2009).

\section{B. Agronomic traits for inbreds \\ Plant materials:}

In 2012, at Nubaria griculture Research Station farm, a total of 15 maize inbred lines (shown in Table 1), were planted to determining agronomic traits for investigated inbred lines.

\section{Experimental procedures:}

Investigated inbred lines evaluated in a randomized complete block design with three replications. Each experimental unit was a three-row plot with a row spacing of $0.75 \mathrm{~m}$ and length of $6 \mathrm{~m}$. Distance between two adjacent plants was $0.25 \mathrm{~m}$ and the population density was approximately 57000 plant $\mathrm{ha}^{-1}$. Standard agronomic farming practices were followed at experiment.

\section{Plant materials:}

\section{Molecular marker tools}

Polymerase chain reaction (PCR) was carried out using the genomic DNA from 15 Maize inbred lines as shown in Table 1. All inbred lines were grown in Nubaria greenhouse at 2012 season.

\section{DNA extraction:}

Bulk of leaf tissues of seven-days old plants from 10 plants from each inbred line (500 mg) were ground to a powder with pestle and mortar in liquid nitrogen $\mathrm{N}_{2}$. The powder was poured into tubes containing 9.0 $\mathrm{ml}$ of warm $\left(65^{\circ} \mathrm{C}\right) \mathrm{CTAB}$ extracting buffer.

\section{ISSR analysis:}

Sequences of 20 primers used for DNA polymorphism (Table 3) obtained from pharmacia Biotech. (Amersham Pharmacia Biotech., UK Limited, HP 79NA, England), were tested in this experiment, to amplify the templated DNA. The ISSR-PCR method was carried out according to Negaoka and Ogihara (1997). Amplification was carried out in $25 \mu 1$ reaction volumes, containing $1 \mathrm{X}$ Taq polymerase buffer $(50 \mathrm{mM} \mathrm{KCl}, 10 \mathrm{mM}$ Tris, $\mathrm{pH} 7.5,1.5 \mathrm{mM} \mathrm{MgCl2}$ ) and 1 unit of Taq polymerase (Pharmacia Biotech, Germany), supplemented with $0.01 \%$ gelatin, $0.2 \mathrm{mM}$ of each dNTPs (Pharmacia Biotech, Germany), 50 pmol of ISSR primers, and $50 \mathrm{ng}$ of total genomic DNA. Amplification was performed in a thermal cycler (Thermolyne Amplitron). After completion of PCR, samples were cooled immediately to $10^{\circ} \mathrm{C}$ and stored at $4{ }^{\circ} \mathrm{C}$ until gel separation. A gel-loading solution $(5 \mu 1)$ was added, and $10 \mu \mathrm{l}$ of the total product volume was resolved in $1.5 \%$ agarose in $1 \mathrm{X}$ TAE buffer for $2 \mathrm{~h}$ aside with a 100-pb ladder (Pharmacia, Germany) as the size standard. Gels were stained in ethedium bromide and images were recorded and photographed on Polaroid films under U. V. light. 
Data handling and cluster analysis:

Data were scored for computer analysis on the basis of the presence of the amplified products for each primer. If a product was present in an inbred line, it was designed as " 1 ", if absent, it was designed as " 0 ", after excluding the irreproducible bands. Pair-wise comparisons of inbred lines, based on the presence or absence of unique and shared polymorphic products, were used to determine similarity coefficient, according to Jaccard (1908).

Table 1. The 15 maize inbred lines, and its genetic background, used in the investigation.

\begin{tabular}{|l|l|l|}
\hline \multicolumn{1}{|c|}{ Serial No. } & \multicolumn{1}{|c|}{ Inbred line } & \multicolumn{1}{c|}{ Source } \\
\hline 1 & Gz 655 & Cargill 922 \\
\hline 2 & Gz 656 & Cargill 922 \\
\hline 3 & Gz 657 & Cargill 922 \\
\hline 4 & Gz 658 & Cargill 922 \\
\hline 5 & Gm1002 & C-17-Tuxpino-1 \\
\hline 6 & Gm1004 & DC-201 \\
\hline 7 & Nb 509 & Population 80 \\
\hline 8 & Nb 517 & Population (Nubaria100273) \\
\hline 9 & Nb579 & Population -40 \\
\hline 10 & Nb582 & Population -40 \\
\hline 11 & Nb603 & Population -40 \\
\hline 12 & Nb612 & Population- 40 \\
\hline 1 & Gz 639* & Population of Sd6273 \\
\hline 2 & Gm $1021^{*}$ & Gemmiza 7421 Population \\
\hline 3 & Nb 552* & Nubaria 73 Ht population \\
$*$ Tester inbred line & & \\
\hline
\end{tabular}

Table 2. Sequences of 20 ISSR primers used for polymorphism.

\begin{tabular}{|c|c|c|}
\hline Serial No. & Primer name & $\begin{array}{c}\text { Nucleotide sequence } \\
5 \ldots \ldots \ldots \ldots \ldots \ldots \ldots .3 \\
\end{array}$ \\
\hline 1 & $\mathrm{AD} 1$ & (AGC)6 G \\
\hline 2 & $\mathrm{AD} 2$ & ( ACC )6 G \\
\hline 3 & AD5 & $(\mathrm{CA}) 10 \mathrm{C}$ \\
\hline 4 & AD7 & $(\mathrm{AG}) 9 \mathrm{C}$ \\
\hline 5 & AD8 & $(\mathrm{AGC}) 6 \mathrm{G}$ \\
\hline 6 & AD9 & $(\mathrm{AC}) 9 \mathrm{G}$ \\
\hline 7 & ADM11 & $(\mathrm{CA}) 6 \mathrm{~A}$ \\
\hline 8 & ADM2 & ( $\mathrm{AC}) 8 \mathrm{CCT}$ \\
\hline 9 & Bra1 & $($ GA $) 9 \mathrm{~T}$ \\
\hline 10 & Bra2 & $($ GGTA $) 4$ \\
\hline 11 & $\mathrm{Bra3}$ & $(\mathrm{GA}) 9 \mathrm{C}$ \\
\hline 12 & $\mathrm{Bra} 4$ & $($ GACA $) 4$ \\
\hline 13 & $\mathrm{Bra} 5$ & $(\mathrm{CCTA}) 4$ \\
\hline 14 & HB13 & $(\mathrm{GAG}) 3 \mathrm{GC}$ \\
\hline 15 & HB15 & ( GTG )3 GC \\
\hline 16 & MGDB1 & ( CA )6 AT \\
\hline 17 & MGDB2 & ( GT )6 CA \\
\hline 18 & MGDB3 & ( AGC ) $4 \mathrm{~T}$ \\
\hline 19 & MGDB4 & $(\mathrm{GCT}) 4 \mathrm{~T}$ \\
\hline 20 & TG1 & $(\mathrm{CAC}) 3 \mathrm{GC}$ \\
\hline
\end{tabular}




\section{Results}

\section{Line-tester experiment}

Analysis of variance of line-tester mating design for grain yield (ton $\mathrm{ha}^{-1}$ ) at the tested locations is presented in Table (3). Mean square of error for the two locations heterogeneous; therefore, the statistical analysis for each location was done separately. Highly significant differences were found among lines, testers, and linetester interaction for grain yield within Nubaria and Gemmiza locations. The interaction line $\mathrm{x}$ tester for grain yield, at tested location indicated that the inbred lines performed differently in their respective test crosses depending on the type of tester used for these traits.

Grain yield as mean performance of topcrosses, for the 12 inbred lines at Nubaria and Gemmiza locations are presented in Tables (4, and 5). The results at Nubaria showed that Nb552 tester had the highest grain yield with the Gz656 and Nb517 inbred lines (5.77 and 5.59 ton ha-1 respectively), while Gz658 and Gm1004 inbred lines have the lowest grain yield with the same tester (3.49 and 3.37 ton ha-1 respectively, Table 4). Gz639 tester had the highest grain yield with the Gz656, Gz657, Gz658 and Gm1002 inbred lines $(6.05,6.01, \quad 5.93$ and 6.27 ton ha-1 respectively), while Nb612 inbred line had the lowest grain yield with the same tester (3.51 ton ha-1, Table 4). Also, the results showed that Gm1021 tester had the highest grain yield with the Gz656 inbred line (7.20 ton ha-1), while Nb517 inbred line had the lowest grain yield with the same tester $(2.16$ ton ha-1, Table 4). Out of 36 single crosses evaluated at Nubaria location, 15 hybrids surpassed grain yield was significantly higher than the check SC173 mean (3.92 ton ha-1), and from those, there the three local commercial hybrids Gz639xGz656 (SC166), Gz639xGz657 (SC167), and Gz639xGz658 (SC168), had mean performance for grain yield 6.05, 6.01, and 5.93 ton ha-1 respectively. Out of the superior 15 hybrids, the new hybrid (Gz656 x Gm1021) yielded 7.20 ton ha-1 topping up all the hybrids under test.

Summarizing the rank of the 36 testcrosses resulting from the 12 lines with the three testers, the top yielding testcross with tester Nb552 were lines Gz656 and Nb517. While with the tester Gz639 the four lines Gz656, Gz657, Gz658, and Gm1002 were the top ranking hybrid. With tester Gm1021, Gz656 gave the best yielding hybrid. It be noticed that Gz656 inbred line had a significant heighest grain yield with the three testers at Nubaria location. Also, the Gz639 tester had the highest grain yield at Nubaria location comparing with $\mathrm{Nb552}$, and Gm1021, (4.88, 4.55, and 4.57 ton/ha, respectevielly).

At Gemmiza location, The results showed that Gm1002 and Nb509 inbred lines had the highest grain yield with the Nb552 tester (6.21 and 6.10 ton ha-1 respectively), while Gm1004 inbred line had the lowest grain yield with the same tester (4.00 ton ha-1, Table 5). Gz639 tester had the highest grain yield with the Gz655 and

Gz657 inbred lines (7.74 and 7.83 ton ha-1 respectively), while $\mathrm{Nb} 582$ and $\mathrm{Nb} 603$ inbred lines have the lowest grain yield with the same tester (4.32 and 4.03 ton ha-1 respectively, Table 5). Gz655 inbred line had the highest grain yield with the Gm1021 tester (8.24 ton ha-1), while $\mathrm{Nb517,} \mathrm{Nb579}$ and $\mathrm{Nb612}$ inbred lines had the lowest grain yield with the same tester $(4.52,5.11$ and 5.11 ton ha-1 respectively, Table 5). 
Table 3. Analysis of variance for grain yield (ton/ha) from line $\mathrm{x}$ tester experiment at Gemmiza and Nubaria locations.

\begin{tabular}{|c|c|c|c|}
\hline \multirow[t]{2}{*}{ S.O.V } & \multirow[t]{2}{*}{ D.F } & \multicolumn{2}{|c|}{$\begin{array}{c}\text { Grain yield } \\
\left(\text { ton } \mathrm{ha}^{-1}\right)\end{array}$} \\
\hline & & Nubaria & Gemmiza \\
\hline Replications & 2 & 1.244 & 8.860 \\
\hline Lines & 11 & $6.347^{* *}$ & $4.580^{* *}$ \\
\hline Testers & 2 & $1.220^{* *}$ & $21.392^{* *}$ \\
\hline Lines $\mathrm{x}$ testers & 22 & $2.589^{* *}$ & $2.959^{* *}$ \\
\hline Error & 70 & $0.227^{\mathrm{a}}$ & $0.933^{\mathrm{b}}$ \\
\hline
\end{tabular}

** Significant and highly significant differences at 0.01 level of probability.

$\mathrm{a}$, and $\mathrm{b}$ indicate heterogeneous error variance for the two locations.

Also, the Gm1021 tester had the highest grain yield mean at Gemmiza comparing with the Nb552, and Gz639 testers (6.49, 4.97, and 5.92 ton/ha, respectivelly).

Comparing the results of the topcrosses of the 12 inbred lines with the three testers indicated that the ranking of the testcross differed from one tester to another due to the effect of general or specific combining ability or both.

For Nb552, both inbred line Gm1002 and $\mathrm{Nb509}$ were the top, while for Gz639 Gz655 and Gz657 were the highest, and only Gz655 was the top hybrid with tester Gm1021.

Table 4. Grain yield means (ton $\mathrm{ha}^{-1}$ ), for 12 lines topcrossed to three testers at Nubaria location.

\begin{tabular}{|c|c|c|c|}
\hline \multirow{2}{*}{ Inbred line } & \multicolumn{3}{|c|}{ Tester (ton ha $\left.{ }^{-1}\right)^{+}$} \\
\hline & $\mathrm{Nb} 552$ & Gz639 & Gm1021 \\
\hline Gz655 & $4.08 \mathrm{def}$ & $5.77 \mathrm{ab}$ & $6.22 \mathrm{~b}$ \\
\hline Gz656 & $5.77 \mathrm{a}$ & $6.05 \mathrm{a}$ & $7.20 \mathrm{a}$ \\
\hline Gz657 & $4.61 \mathrm{bcd}$ & $6.01 \mathrm{a}$ & $6.18 \mathrm{~b}$ \\
\hline Gz658 & $3.49 \mathrm{f}$ & $5.93 \mathrm{a}$ & $4.94 \mathrm{c}$ \\
\hline Gm1002 & 4.51 cde & $6.27 \mathrm{a}$ & $4.86 \mathrm{c}$ \\
\hline Gm1004 & $3.37 \mathrm{f}$ & $4.28 \mathrm{~cd}$ & $3.75 \mathrm{de}$ \\
\hline Nb509 & $4.16 \mathrm{def}$ & $5.02 \mathrm{bc}$ & $4.37 \mathrm{~cd}$ \\
\hline Nb517 & $5.59 \mathrm{a}$ & $3.56 \mathrm{de}$ & $2.16 \mathrm{f}$ \\
\hline Nb579 & $4.71 \mathrm{bcd}$ & $4.07 \mathrm{de}$ & $3.90 \mathrm{de}$ \\
\hline Nb582 & 3.70 ef & $3.74 \mathrm{de}$ & $3.15 \mathrm{e}$ \\
\hline Nb603 & $5.33 \mathrm{ab}$ & $4.32 \mathrm{~cd}$ & $4.30 \mathrm{~cd}$ \\
\hline Nb612 & $5.27 \mathrm{abc}$ & $3.51 \mathrm{e}$ & $3.77 \mathrm{de}$ \\
\hline Mean & $4.55 \mathrm{c}$ & $4.88 \mathrm{a}$ & $4.57 \mathrm{~b}$ \\
\hline SC173 & & & \\
\hline
\end{tabular}

+ Means followed by the same letter are not differed according to $\mathrm{FLSD}_{0.05}$. 
Table 5. Grain yield means (ton $\mathrm{ha}^{-1}$ ), for 12 lines topcrossed to three testers at Gemmiza location.

\begin{tabular}{|c|c|c|c|}
\hline Inbred line & \multicolumn{3}{|c|}{ Tester $\left(\text { ton } \mathrm{ha}^{-1}\right)^{+}$} \\
\hline & $\mathrm{Nb}_{552^{+}}$ & ${\mathrm{Gz} 639^{+}}^{+}$ & $\mathrm{Gm} 1021^{+}$ \\
\hline Gz655 & $4.10 \mathrm{bc}$ & $7.74 \mathrm{a}$ & $8.24 \quad \mathrm{a}$ \\
\hline Gz656 & $5.40 \mathrm{ab}$ & $6.19 \mathrm{bc}$ & $7.76 \mathrm{ab}$ \\
\hline Gz657 & $4.27 \mathrm{bc}$ & $7.83 \mathrm{a}$ & $7.30 \mathrm{abc}$ \\
\hline Gz658 & $4.32 \mathrm{bc}$ & $6.13 \mathrm{bc}$ & 7.38 abc \\
\hline Gm1002 & $6.21 \quad \mathrm{a}$ & $5.58 \mathrm{bcd}$ & $7.06 \mathrm{abc}$ \\
\hline Gm1004 & $4.00 \mathrm{c}$ & $6.11 \mathrm{bc}$ & $5.93 \mathrm{bcd}$ \\
\hline Nb509 & $6.10 \mathrm{a}$ & $6.57 \mathrm{~b}$ & $7.68 \mathrm{ab}$ \\
\hline $\mathrm{Nb5} 17$ & $5.17 \quad a b c$ & $6.55 \mathrm{~b}$ & $4.52 \mathrm{~d}$ \\
\hline Nb579 & $4.93 \mathrm{abc}$ & 5.17 cde & $5.11 \mathrm{~d}$ \\
\hline $\mathrm{Nb582}$ & $4.90 \quad a b c$ & $4.32 \mathrm{e}$ & $5.63 \mathrm{~cd}$ \\
\hline $\mathrm{Nb603}$ & $5.32 \mathrm{abc}$ & $4.03 \mathrm{e}$ & 6.22 bcd \\
\hline $\mathrm{Nb612}$ & $4.91 \mathrm{abc}$ & $4.80 \mathrm{de}$ & $5.11 \mathrm{~d}$ \\
\hline Mean & $4.97 \mathrm{c}$ & $5.92 \mathrm{~b}$ & $6.49 \mathrm{a}$ \\
\hline SC173 & & 4.03 & \\
\hline
\end{tabular}

+ Means followed by the same letter are not differed according to $\operatorname{FLD}_{0.05}$.

\section{HSGCA (Heterotic group's from line-tester experiment) \\ Nubaria:}

The inbred lines were divided into groups depending on its general combining ability plus its specific combining ability with every tester used in the line $\mathrm{x}$ tester experiment at the tested location according to the following steps.

Step1: Place all inbred lines (the 12 inbred lines) into the same heterotic group as their tester, in this step all the 12 inbred lines placed into each tester heterotic group, (Table 6,).

Step 2:Kept the inbred line with the heterotic group where its HSGCA effects (Heterotic relying on Specific and General combining Ability effects) had the smallest value or largest negative value (Table 6).

Step 3:If the inbred line had positive HSGCA effect with all representative testers, it will be cautious to assign that line to any heterotic group, to get final groups.

Group 1 (Nb552): Gz655, Gz658, Gm1002, Gm1004, and Nb509. Group 2 (Gz639): Nb579, Nb603, and Nb612, Group 3 (Gm1021): Nb517, and Nb582.

\section{Gemmiza:}

The inbred lines were divided into groups depending on its general combining ability plus its specific combining ability with every tester used in the line $\mathrm{x}$ tester experiment at the tested location according to the following steps.

Step1: Place all inbred lines (12 inbred lines) into the same heterotic group as their tester, in this step all the 12 inbred lines placed into each tester heterotic group, (Table 7).Step 2: Kept the inbred line with the heterotic group where its HSGCA effects (Heterotic relying on Specific and General combining Ability effects) had the smallest value or largest negative value.Step 3: If the inbred line had positive HSGCA effect with all representative testers, it will be cautious to assign that line to any heterotic group, to get final groups. Group 1 (Nb552): Gz655, Gz657, Gz658, and Gm1004.Group 2 (Gz639): Gm1002, Nb582, and Nb603.Group 3 (Gm1021): Nb517, $\mathrm{Nb} 579$, and $\mathrm{Nb612.}$ 
Table 6. HSGCA values depending on grain yield from line-tester experiment at Nubaria location for 12 inbred lines with three testers.

\begin{tabular}{|l|c|c|c|}
\hline Inbred line & HSGCA (Nb.552) & HSGCA (G639) & HSGCA (Gm1021) \\
\hline Gz655 & -0.47 & 0.89 & 1.65 \\
\hline Gz656 & 1.22 & 1.17 & 2.63 \\
\hline Gz657 & 0.06 & 1.13 & 1.61 \\
\hline Gz658 & -1.06 & 1.05 & 0.37 \\
\hline Gm1002 & -0.04 & 1.39 & 0.29 \\
\hline Gm1004 & -1.18 & -0.6 & -0.82 \\
\hline Nb509 & -0.39 & 0.14 & -0.2 \\
\hline Nb517 & 1.04 & -1.32 & -2.41 \\
\hline Nb579 & 0.16 & -0.81 & -0.67 \\
\hline Nb582 & -0.85 & -1.14 & -1.42 \\
\hline Nb603 & 0.78 & -0.56 & -0.27 \\
\hline Nb612 & 0.72 & -1.37 & -0.8 \\
\hline
\end{tabular}

Table 7. HSGCA values depending on grain yield from line-tester experiment at Gemmiza location for 12 inbred lines with three testers.

\begin{tabular}{|l|c|c|c|}
\hline Inbred line & HSGCA (Nb552) & HSGCA (Gz639) & HSGCA (Gm1021) \\
\hline Gz655 & -0.87 & 1.82 & 1.74 \\
\hline Gz656 & 0.43 & 0.27 & 1.26 \\
\hline Gz657 & -0.7 & 1.91 & 0.8 \\
\hline Gz658 & -0.65 & 0.21 & 0.88 \\
\hline Gm1002 & 1.24 & -0.34 & 0.56 \\
\hline Gm1004 & -0.97 & 0.19 & -0.57 \\
\hline Nb509 & 1.13 & 0.65 & 1.18 \\
\hline Nb517 & 0.2 & 0.63 & -1.98 \\
\hline Nb579 & -0.04 & -0.75 & -1.39 \\
\hline Nb582 & -0.07 & -1.6 & -0.87 \\
\hline Nb603 & 0.35 & -1.89 & -0.28 \\
\hline Nb612 & -0.06 & -1.12 & -1.39 \\
\hline
\end{tabular}

\section{Agronomic characters for inbred lines}

Grouping inbred lines using agronomic characters

Mean performance of the 12 inbred lines per se in agronomic and morphological characters is presented in Tables $(8,9$, and 10$)$.

Grouping of tested inbred lines by cluster analysis for its agronomic characters using Wards minimum variance method (Ward, 1963), and using NCSS10 software are presented in figure 3. Results showed that only seven inbred lines were divided into two heterotic groups as follow: 
Table 8. Mean performance of number of days to mid-silking, plant height, ear height, grain yield, ear length, and weight of 100 grains for 15 inbred lines grown at Nubaria in 2012 season.

\begin{tabular}{|c|c|c|c|c|c|c|}
\hline Inbred line & $\begin{array}{c}\text { Number of days } \\
\text { to } \\
\text { mid-silking }\end{array}$ & Plant height $(\mathrm{cm})$ & Ear height $(\mathrm{cm})$ & $\begin{array}{c}\text { Grain yield } \\
\left(\text { g.plant }{ }^{-1}\right)\end{array}$ & Ear length $(\mathrm{cm})$ & $\begin{array}{c}100 \text { grains } \\
\text { weight }(\mathrm{gm})\end{array}$ \\
\hline Gz655 & $70.3 \mathrm{~b}$ & $103.3 \mathrm{fg}$ & $61.6 \mathrm{def}$ & $49.01 \mathrm{abc}$ & $13.9 \mathrm{abc}$ & $22.84 \mathrm{gh}$ \\
\hline Gz656 & $71.6 \mathrm{a}$ & $118.0 \mathrm{de}$ & $68.3 \mathrm{bcd}$ & $55.45 \mathrm{abc}$ & $14.5 \mathrm{ab}$ & 25.10 defg \\
\hline Gz657 & $70.0 \mathrm{~b}$ & 114.0 defg & $70.6 \mathrm{bc}$ & $40.03 \mathrm{bcd}$ & $12.8 \mathrm{cde}$ & $25.63 \mathrm{cdef}$ \\
\hline Gz658 & $70.6 \mathrm{~b}$ & 120.6 bcde & $74.0 \mathrm{ab}$ & $42.72 \mathrm{bcd}$ & $12.3 \mathrm{def}$ & $22.27 \mathrm{~h}$ \\
\hline Gm1002 & $61.6 \mathrm{e}$ & $127.0 \mathrm{abcd}$ & 63.3 cde & $20.98 \mathrm{~d}$ & $10.9 \mathrm{~g}$ & $27.17 \mathrm{bcd}$ \\
\hline Gm1004 & $66.6 \mathrm{~d}$ & $102.0 \mathrm{~g}$ & $60.3 \mathrm{def}$ & $60.33 \mathrm{ab}$ & 11.9 efg & $17.65 \mathrm{i}$ \\
\hline Nb509 & $58.6 \mathrm{fg}$ & 108.3 efg & $53.0 \mathrm{fg}$ & $65.33 \mathrm{ab}$ & 12.0 efg & $23.47 \mathrm{fgh}$ \\
\hline Nb517 & $59.3 \mathrm{f}$ & $133.6 \mathrm{ab}$ & $55.6 \mathrm{efg}$ & $65.89 \mathrm{ab}$ & $13.6 \mathrm{bcd}$ & $25.61 \mathrm{def}$ \\
\hline Nb579 & $61.3 \mathrm{e}$ & $120.0 \mathrm{cde}$ & $50.3 \mathrm{~g}$ & $57.74 \mathrm{ab}$ & $13.9 \mathrm{abc}$ & $25.86 \mathrm{cdef}$ \\
\hline Nb582 & $61.3 \mathrm{e}$ & $137.3 \mathrm{a}$ & 80.6 a & $31.57 \mathrm{~cd}$ & $11.0 \mathrm{fg}$ & $29.11 \mathrm{~b}$ \\
\hline Nb603 & $61.0 \mathrm{e}$ & $124.0 \mathrm{abcd}$ & $66.0 \mathrm{bcd}$ & $64.31 \mathrm{ab}$ & $13.1 \mathrm{cde}$ & 26.58 cde \\
\hline Nb612 & $58.6 \mathrm{fg}$ & $116.6 \mathrm{def}$ & 56.6 efg & $63.61 \mathrm{ab}$ & $12.0 \mathrm{efg}$ & 37.76 a \\
\hline Gz639 & $68.6 \mathrm{c}$ & $131.6 \mathrm{abc}$ & $74.0 \mathrm{ab}$ & $58.53 \mathrm{ab}$ & $15.2 \mathrm{a}$ & 24.12 efgh \\
\hline Gm1021 & $66.0 \mathrm{~d}$ & $125.3 \mathrm{abcd}$ & $64.0 \mathrm{cde}$ & $49.82 \mathrm{abc}$ & $12.4 \mathrm{def}$ & $28.12 \mathrm{bc}$ \\
\hline Nb552 & $58.0 \mathrm{~g}$ & $132.6 \mathrm{abc}$ & $66.3 \mathrm{bcd}$ & $68.44 \mathrm{a}$ & $14.5 \mathrm{ab}$ & $22.07 \mathrm{~h}$ \\
\hline
\end{tabular}

Means had the same letters are significantly equals.

Group 1: Gz656, Gz657, and Gz658. Group 2: Nb579, Nb603, and Nb612.

But the Gm1002, Gm1004, Nb509, Nb517, and Nb582 inbred lines were not grouped because morphological characters were not sufficient for grouping them.

Disagreement between grouping based on pedigree and that based on morphological character was found in this study. Heckenberger, et al (2005) reported that morphological distance have disadvantages first, assessment of morphological traits requires extensive field trails across several years and locations to minimize environmental effect. These measurements are therefore more expensive and time consuming. Second, the scoring of morphological traits is subjective to certain extent; therefore number of check inbred lines must be included in the study to warrant a high quality of morphological traits across different years and scoring persons. 


\section{Grouping inbred lines using ISSR-markers}

Grouping 12 inbred lines using 10 Inter-Simple Sequence Repeats (ISSR) markers are presented in figure 4. Results showed that the 12 inbred lines are grouped into five groups as follows: Group 1: Gm1002, and Nb517.Group 2: Nb509, Nb579, and Nb582.Group 3: Gz655, Gz656, Gz657, and Gz658 Group 4: Gm1004, Nb603, and Nb612.

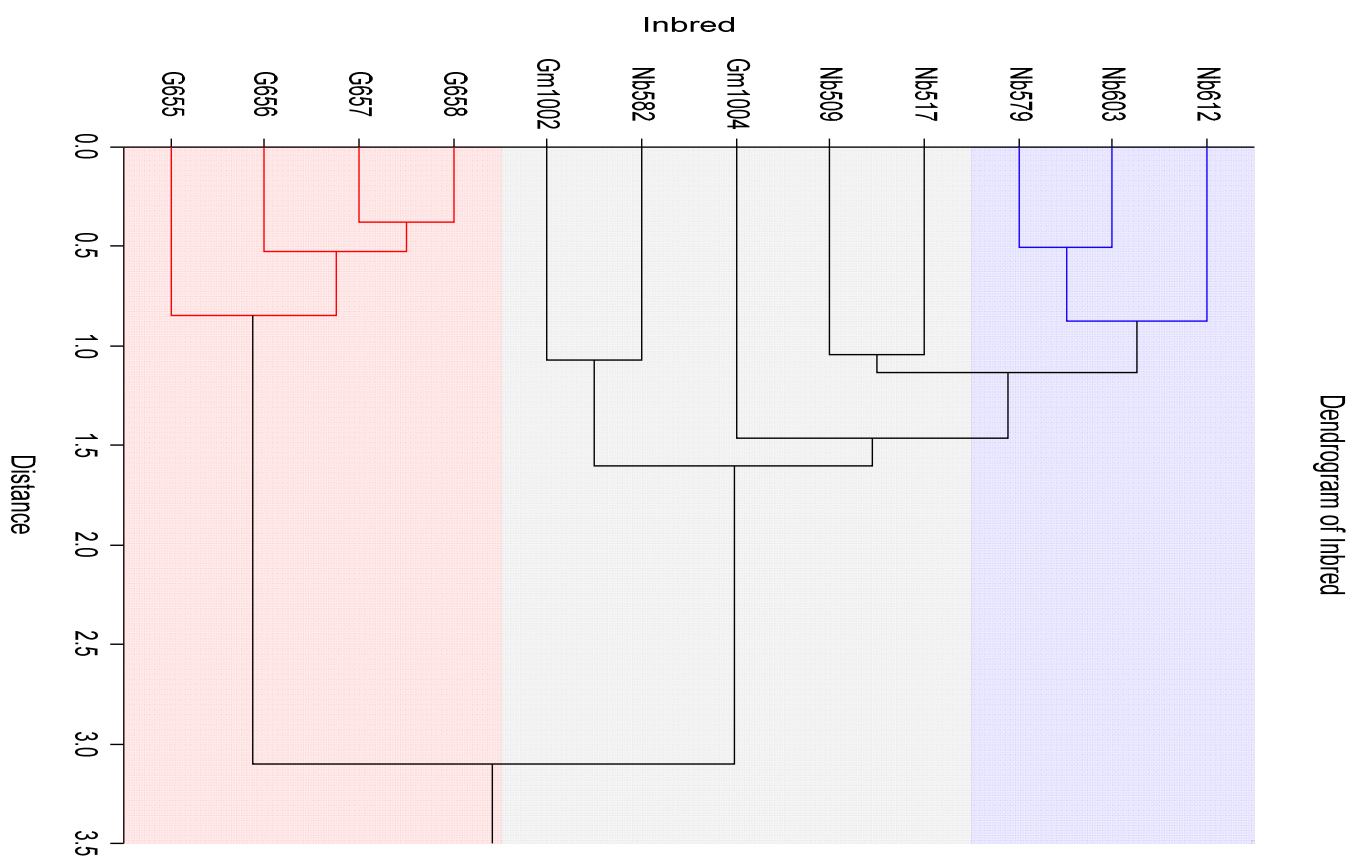

Fig. 3. Clustering inbred lines using 19 agronomic characters.

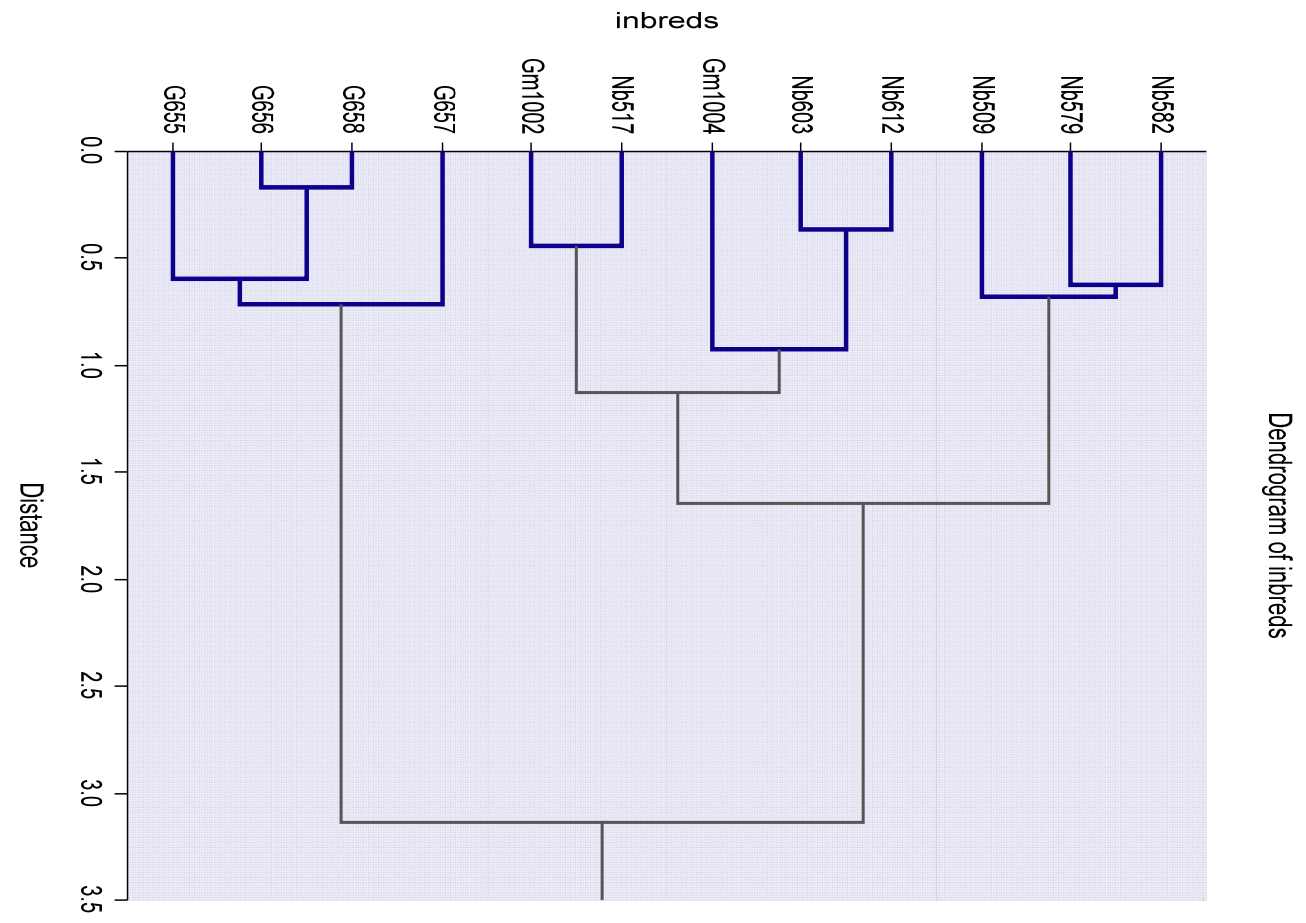

Fig. 4. Cluster analysis of the 12 maize inbred lines using ISSR markers. 


\section{Discussion}

Different relatedness inbred lines were used in this investigation, inbred lines were sister lines in F3 stage and differed after yet (these released from Cargill 922), inbred lines from the same population but were not sister lines at any stage (Pop.40 released inbred lines), and other inbred lines are released from totally different sources (Gemmiza inbred lines), and that was to have a real vision how far could each used method detect these degrees of relatedness. The classification due to molecular markers have agreement with pedigree data more than the HSGCA and agronomic characters methods, because that the HSGCA method affected by testers, lines, and environments, also, agronomic character method need to plant the inbred lines and evaluate them at more location and more season and may need more planting date in the season, furthermore, all these cautions will not discard the environmental effects but they will reduce it to the minimum values. On the other hand, molecular marker will keep time and efforts needed to evaluate the inbred lines, also, molecular markers will discard the environmental effects on genetic distances determination.

The marker data is more accurate comparing with other classifying methods. Aguiar et al (2008) reported that, the formation of heterotic groups using information from test crosses is tester dependent. The discriminate of heterotic groups based on estimates of genetic diversity obtained with molecular marker data, on the other hand, is not influenced by environment interaction. Besides requiring less time, since no crosses has to be formed. Heckenberger et al (2005) reported that morphological distance and mid-parent agronomic heterosis have several disadvantages compared with molecular markers, first, assessment of morphological traits and mid-parent agronomic heterosis requires extensive field trails across several years and locations to minimize environmental effect. These measurements are therefore more expensive and time consuming than molecular marker analyses. Second, agronomic heterosis estimates requires production and testing of hybrids. In addition, reciprocal crosses should be evaluated to minimize risk of maternal effects. Third, the scoring of morphological traits is subjective to certain extent; therefore number of check inbred lines must be included in the study to warrant a high quality of morphological traits across different years and scoring persons. Xiang et al., (2010) found disagreement between heterotic groups based on specific combining ability and that based on molecular markers. For assessment of genetic diversity, molecular markers have been generally superior to morphological, pedigree, heterosis, and biochemical data (isozymes and chromatography), (Melchinger et al. 1991; Melchinger et al. 1992). Reif et al. (2003) reported that field trials for identification of promising heterotic patterns can be planned more efficiently based on prior information obtained from SSR molecular markers. Bruel, et al. (2006) concluded that the genetic distance revealed by RAPD markers can be used to establish consistent heterotic patterns between maize inbred lines. In contrast, Semagn et al. (2012) reported that there was no correlation between heterotic groupings based on Phenotypic and single nucleotide polymorphic markers. Estimated of relatedness based on pedigree data can differ from those based on molecular marker data (Bernardo and Kahler, 2001).

In Conclusion: Maize breeder should use ISSR molecular marker similarity data side by side with the pedigree information before crosses made to assist heterotic groups from maize inbred lines in breeding field reducing to efforts and money towards catching super crosses, also, data for grouping inbred lines according to HSGCA method, or 
morphological characters for inbred lines per se are not sufficient for grouping Maize inbred lines, and grouping will be affected by the environment so far.

\section{References}

Aguiar, C. G., Schuster, I., Junior, A. T. A., Scapim, C. A. and Vieira, E. S. N. (2008) Heterotic groups in tropical maize germplasm by test crosses and simple sequence repeat markers, Genet. Mol. Res., 7 (4): 1233-1244.

Bernardo, R. and Kahler, A. (2001) North American study on essential derivation in maize inbreds developed without and with selection from F2 populations, Theor. Appl. Genet., 102: 986-992.

Betran, F. J., Ribaut, J. M., Beck, D. and de Leon, D. G. (2003) Genetic diversity, specific combining ability, and heterosis in tropical maize under stress and nonstress environments, Crop Sci., 43: 797- 806.

Betran, F. J., Ribaut, J. M., Beck, D. and de Leon D. G. (2003) Genetic diversity, specific combining ability, and heterosis in tropical maize under stress and nonstress environments, Crop Sci. 43: 797-806.

Bruel D. C., Pipelo V. C., Gerage A. C., Junior N. S. F., Prete C. E. C., Ruas C. F., Ruas P., MSouza S. G. H. and Garbuglio D. D. (2006) Genetic distance estimated by RAPD markers and its relationship with hybrid performance in maize, Pesq. Agropec. Bras., 41 (10): $1491-1498$

Fan X. M. , Zhang Y. M., Yao W. H., Chen H. M., Tan J., Xu C. X., Han X. L., Luo L. M. and Kang M. S. (2009) Classifying maize inbred lines into heterotic groups using a factorial mating design, Agron. J., 101: 106-112.

Hallauer A. R., Russell W. A., Lamkey K. R., (1988) Corn breeding p.463 - 564. In :corn and corn improvement. (Eds.) G. F. Sprague and J. W. Dudley, Am. Soc. Agron., Madison, Wisconsin, USA.

Hays, H. K. (1956) I. Saw hybrid corn develop, pp: 48-81, In Dolores Wilknson (ed.) Eleventh hybrid corn industryresearch conference. 28 - 29 Nov. Hyatt Regency Hotel Chicago. IL. AM. Seed Trade Assoc. $60113^{\text {th }}$ St. NW. Suite 570. Washington. DC.

Heckenberger, M., Bohn, M., Klein, D. and Melchinger, A. E. (2005) Identification of essentially derived varieties obtained from biparental crosses of homozygous lines: II morphological distances and heterosis in comparison with simple sequence repeat and amplification length polymorphism data in maize, Crop Sci. 45: 1132 - 1140 .

Jaccard, P. (1908) Nouvelles researches sur la distribution florale, Bull. Soc. Vaudoise Sci. Natl., 44: 223-270.

Kempthorne, O. (1957) An introduction to genetic statistical. John Wiley-Sons Inc. New Yourk, USA.
Lee, E. A., Ash, M. J. and Good, B. (2007) Re-examining the relationship between degree of relatedness, genetic effects, and heterosis in maize, Crop Sci., 47: 629-635.

Melchinger, A. E. and Gumber, R. K. (1998) Overview of heterotic groups in agronomic crops, pp: 29-44, In: K. R. Lamkey, J. E. Staub (Eds.), Concepts and breeding of heterosis in crop plants, CSSA. Madison, WI.

Melchinger, A. E., Boppenmaier, J., Dhillon, B. S., Pollmer, W. G. and Herrmann, R. G. (1992) Genetic diversity for RFLPs in European maize inbreds. II. Relation to the performance of hybrids within versus between groups for forage trait, Theor. Appl. Genet., 84: 672-681.

Melchinger, A. E., Lee, M., Lamkey, K. R., Hallauer, A. R. and Woodman, W. L. (1990) Genetic diversity for restriction fragment length polymorphism and heterosis for two diallel sets of maize inbreds, Theor. Appl. Genet, 80: 488-496.

Nagaoka, T. and Ogihara, Y. (1997) Applicability of intersimple sequence repeat polymorphisms in wheat for use as DNA markers in comparison to RFLP and RAPD markers, Theor. Appl. Genet., 94: 597-602.

Reif J. C., Melchinger A. E., Xia X. C., Warburton M. L., Hoisington S. A., Vasal S. K., Beck D., Bohn, M. and Frish, M. (2003a) Use of SSRs for establishing heterotic groups in subtropical maize, Theor. Appl. Genet, 107: 947957.

Reif, J. C., Melchinger, A. E., Xia, X. C., Warburton, M. L., Hoisington, S. A., Vasal, S. K., Beck, D., Bohn, M. and Frish, M. (2003b) Genetic distance based on simple sequence repeats and heterosis in tropical maize populations, Crop Sci., 43: 1275-1282.

Reif, J. C., Hallauer, A. R. and Melchinger, A. E. (2005) Heterosis and heterotic patterns in maize, Maydica, 50: 215-223.

Schnell, F. W. (1982) A synoptic study of the methods and categories of plant breeding, Z. pflanzen zuchtung, 89: 118 .

Semagn, K., Magorokosho, C., Vivek, B. S., Makumbi, D., Beyene, Y., Mugo, S., Prasanna, B.M. and Warburton, M. L. (2012) Molecular characterization of diverse CIMMYT maize inbred lines from eastern and southern Africa using single nucleotide polymorphic markers, $B M C$ Genomics, 13, 113.

Ward, J. H. Jr. (1963) Hierarchial grouping to optimize an objective function, J. Am. Statist. Assoc., 58: 236-244.

Xiang, K., Yang, K. C., Pan, G. T., Reid, L. M., Li, W. T., Zhu, X. and Zhang, Z. M. (2010) Genetic diversity and classification of maize landraces from China's Sichuan Basin based on agronomic traits, quality traits, combining ability and SSR markers, Maydica, 55: 85-93. 


\section{طرق مختلفة لعمل مجوعات متباعدة وراثيًا في الذرة الثامية}

محمد ممدوح الرويي، ومحمد حسن الثيخ، وأحمد عبدالمنعم حبليزة*، وعماد إسماعيل محمود*

قسم الدحاصيل، كلية الزراعة (الثاطبي)، جامعة الإسكندرية

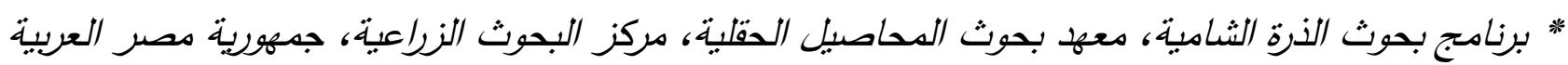

المستخلص. أجريت مقارنة بعض طرق تقسيم با سلالة من الذرة الثامية إلى مجوعات متباعدة ورانيًا، باستخدام تأثيرات القدرتين العامة والخاصة على الايتّلاف وبعض الصفات المورفولوجية على السلالات

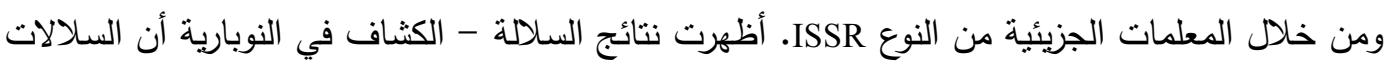

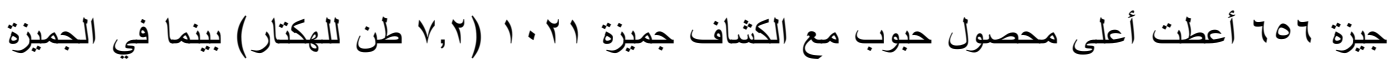

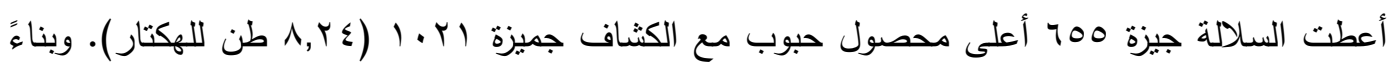

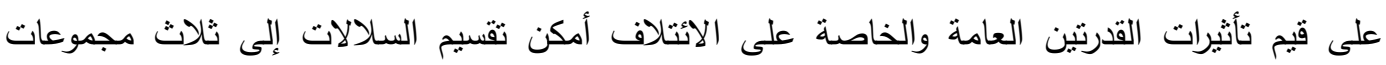

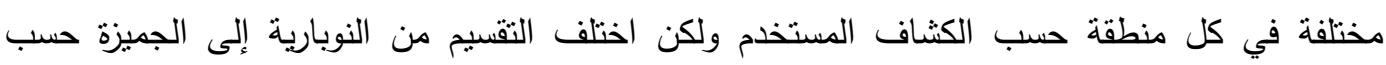

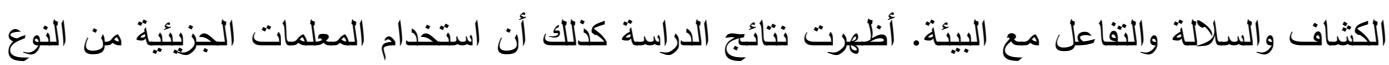

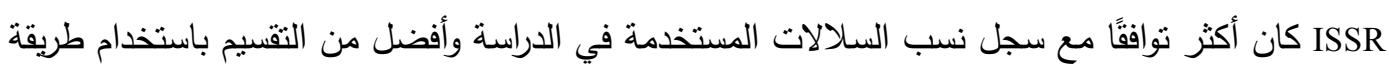
HSGCA

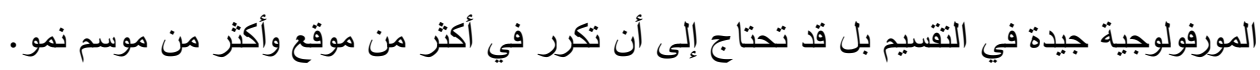

